\title{
Mechanisms for estrogen receptor expression in human cancer
}

\author{
Hui Hua ${ }^{1 *}$, Hongying Zhang ${ }^{2}$, Qingbin Kong ${ }^{2}$ and Yangfu Jiang ${ }^{2}$
}

\begin{abstract}
Estrogen is a steroid hormone that has critical roles in reproductive development, bone homeostasis, cardiovascular remodeling and brain functions. However, estrogen also promotes mammary, ovarian and endometrial tumorigenesis. Estrogen antagonists and drugs that reduce estrogen biosynthesis have become highly successful therapeutic agents for breast cancer patients. The effects of estrogen are largely mediated by estrogen receptor (ER) a and ER $\beta$, which are members of the nuclear receptor superfamily of transcription factors. The mechanisms underlying the aberrant expression of ER in breast cancer and other types of human tumors are complex, involving considerable alternative splicing of ERa and ERß, transcription factors, epigenetic and post-transcriptional regulation of ER expression. Elucidation of mechanisms for ER expression may not only help understand cancer progression and evolution, but also shed light on overcoming endocrine therapy resistance. Herein, we review the complex mechanisms for regulating ER expression in human cancer.
\end{abstract}

Keywords: Cancer, Estrogen receptor, Transcription, Epigenetic modification

\section{Background}

Estrogens are steroidal hormones that function as the primary female sex hormone. There are three major forms of estrogen, namely estrone (E1), estradiol (E2) and estriol (E3). Estradiol (E2) is the predominant estrogen in nonpregnant females, while estrone and estriol are primarily produced during pregnancy and following the onset of menopause [1], respectively. $17-\beta$-estradiol is the primary estrogen from menarche to menopause [2]. All estrogens are produced from androgens through actions of enzymes such as aromatase [3]. Follicle-stimulating hormone and luteinizing hormone stimulate the synthesis of estrogen in the ovaries [4]. However, some estrogens are also produced in smaller amounts by other tissues such as the liver, adrenal glands, and mammary gland [5]. Previous studies suggest that estrogen is associated with mammary tumorigenesis, ovarian and endometrial carcinogenesis [6]. Also, mounting evidence demonstrate that estrogen and its target gne progesterone receptor

\footnotetext{
*Correspondence: huahuihuaxi@163.com

${ }^{1}$ Laboratory of Stem Cell Biology, West China Hospital, Sichuan University, Chengdu, China

Full list of author information is available at the end of the article
}

(PR) play critical roles in regulatiing breast cancer progression and cancer stem cell fate [7, 8]. However, estrogen may have anti-cancer effects in some organs such as the liver and colon, whilst more studies are needed to clarify this argument and better understand the mechanisms [9-12].

The biological effects of estrogen are mostly mediated by its binding and activation of $E R \alpha$ and $E R \beta$, which are members of the nuclear receptor superfamily of transcription factors that are characterized by highly conserved DNA- and ligand-binding domains $[3,13]$. The DNA binding domain, which is extremely well conserved between ER $\alpha$ and ER $\beta$ (97\% homology), contains two functionally distinct zinc finger motifs that are responsible for specific DNA binding, as well as mediating receptor dimerization [3]. The unliganded ER has been shown to be present in a cytosolic complex with hsp90 and associated proteins, with ligand binding allowing dissociation from the hsp90 complex, receptor dimerisation, nuclear localisation and binding to estrogen response elements (ERE, 5'-AGGTCAnnnTGACCT-3') in promoters of estrogen-regulated genes [14, 15]. Genome-wide chromatin immunoprecipitation studies have confirmed that the majority of ER-binding sites in estrogen responsive

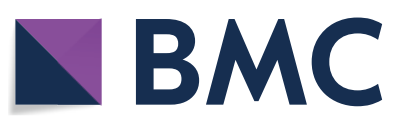

(c) The Author(s) 2018. This article is distributed under the terms of the Creative Commons Attribution 4.0 International License (http://creativecommons.org/licenses/by/4.0/), which permits unrestricted use, distribution, and reproduction in any medium, provided you give appropriate credit to the original author(s) and the source, provide a link to the Creative Commons license, and indicate if changes were made. The Creative Commons Public Domain Dedication waiver (http://creativecommons.org/ publicdomain/zero/1.0/) applies to the data made available in this article, unless otherwise stated. 
genes conform well to this consensus sequence [16]. While ER $\alpha$ and ER $\beta$ can bind to most ERE identically, the differences in ER $\alpha$ and ER $\beta$ may lead to tethering differential transcription factors and then modulating different target genes $[17,18]$. Thus, the activation of ER $\alpha$ or ER $\beta$ can produce both unique and overlapping effects.

$E R \alpha$ has also been shown to modulate gene transcription through heterodimerizing with other transcription factors such as activating protein 1 (AP1) and nuclear factor kappa-light-chain-enhancer of activated B cells $(\mathrm{NF}-k \mathrm{~B})[19,20]$. There is a large profile of estrogenresponsive genes, including $\mathrm{pS} 2$, cathepsin $\mathrm{D}, \mathrm{c}$-fos, c-jun, c-myc, TGF- $\alpha$, retinoic acid receptor $\alpha 1$, efp, progesterone receptor (PR), insulin-like growth factor 1 (IGF1) [21]. Many of these ER-regulated genes, including IGF1, cyclin D1, c-myc, and efp, are important for cell proliferation and survival. C-myc is a bona-fide oncogene that is amplified or overexpressed in a variety of human tumors [22]. Efp is an ubiquitin ligase that promotes proteasomal degradation of 14-3-3 sigma thereby stimulating cellular proliferation [23]. While PR is an estrogenresponsive gene, it may antagonize ER $\alpha$ action to inhibit tumor growth, paticulary through interating with RNA polymerase III and inhibiting tRNA transcription [24].

Notably, a pool of ER $\alpha$ are located in the plasma membrane and cytoplasm [25], where it binds to diverse membrane or cytoplasmic signaling molecules such as the p85 regulatory subunit of class I phosphoinositide 3-kinase, mitogen-activated protein kinase (MAPK) and Src [26, 27]. Activation of these signal transduction pathways by estrogen initiates cell survival and proliferation signals. Additionally, these signaling molecules are able to phosphorylate the ER $\alpha$ and its co-regulators to augment nuclear ER $\alpha$ signaling [28]. The genomic and non-genomic actions of ER $\alpha$ play a crucial role in breast epithelial cell proliferation and survival, as well as mammary tumorigenesis [28]. The purpose of this review is to decipher the complex mechanisms underlying the abberant expression of ER $\alpha$ and $E R \beta$ in human cancer.

\section{Expression of ER in normal tissues}

The human ER $\alpha$ and ER $\beta$ cDNA were cloned in 1985 and 1986, respectively [29, 30]. In human mammary gland, $E R \alpha$ positive cells are present in ducts and lobules, but not in stromal cells. ER $\alpha$ expression is largely heterogeneous within different areas of breast tissue. Only a small fraction of epithelial cells in ducts and lobules are $\mathrm{ER} \alpha$-positive [31]. The ER $\alpha$ levels in mammary gland are affected by menstrual cycle, with more ER $\alpha$-positive cells in the follicle stage of the cycle [32]. ER $\alpha$-positive epithelial cells may promote proliferation of surrounding ER $\alpha-$ negative cells, probably through secretion of paracrine factors [33]. While ER $\alpha$ is expressed in luminal epithelial cells but not in the stroma, ER $\beta$ is present in luminal, myoepithelial and stromal cells [7]. Depletion of ER $\alpha$ leads to failure to initiate the pre- and postpubertal stages of mammary gland growth, as well as pregancy-induced maturation [34]. ER $\beta$ knockout, however, has little effects on mammary gland development [35]. In addition, ER $\alpha$ expression is also detectable in endometrium and ovary. ER $\alpha$ knockout severely disrupts sexual maturation of the whole reproductive tract [36]. ER $\beta$ knockout, however, predominantly disrupts the maturation of ovarian function [37].

ER $\alpha$ and ER $\beta$ are both expressed in other cell types, though at lower levels than those found in reproductive tissues. Myeloid and lymphoid progenitor cells, mature lymphocytes, and neutrophils express $E R \alpha, E R \beta$, or both receptors [38]. Although 17- $\beta$-estradiol inhibits $\mathrm{T}$ and $\mathrm{B}$ cell development, it enhances $\mathrm{B}$ cell function in ER $\alpha$-dependent manner, involving both genomic and non-genomic ER signaling in B lymphocytes [39, 40]. Moreover, the brain of both sexes is a major target of estradiol and a site of estrogen synthesis $[41,42]$. ER $\beta$ is a dominant ER subtype in the adult cerebellum. ER $\beta$ expression was detected in Golgi type neurons, Purkinje cells, and basket cells in the adult cerebellum [43]. High levels of ER $\alpha$ expression are also found in the hypothalamus, with particularly elevated expression within the medial preoptic area, as well as the amygdala and ventral medial hypothalamus [44]. Estrogen and its receptors may improve memory and social behaviors, regulate brain lipid metabolism and prevent cortical damage following an ischemic episode [45-47]. In addition, estrogen and ER are important for bone homeostasis, hepatic lipid metabolism and reverse cholesterol transport [48, 49]. While the liver predominatly expresses ER $\alpha$, the gastointestinal tract and the lung exclusively harbour ER $\beta$ [50]. Moreover, both ER $\alpha$ and ER $\beta$ are expressed in platelets [51]. An estrogen analogue is able to induce platelets apoptosis and autophagy [52]. Therefore, ER is a vital hormone receptor for human health.

\section{Expression of ER in human tumors}

Based on the ER status, breast tumors can be classified as ER-positive and ER-negative. About 75\% of breast cancer cases are ER $\alpha$ positive at diagnosis [53]. Luminal A and basal subtypes are two major subtypes of human breast cancer. ER $\alpha$ is more frequently expressed in luminal $\mathrm{A}$ tumors than in basal tumors [54]. ER $\alpha$-positive cases are not only responsive to endocrine therapies, but also sensitive to CDK4/ 6 inhibitors $[55,56]$. Thus, ER positivity may be associated with a better prognosis [57]. ER $\alpha$ negative tumors, on the other hand, are more aggressive and metastatic [58]. Importantly, ER $\alpha$ expression in breast cancer is dynamic and reversible. About 50\% of 
patients with ER $\alpha$-positive primary breast tumors that relapse after adjuvant endocrine therapy have recurrent tumors in which ER $\alpha$ expression is lost [59]. The ER $\alpha$ negative and human epidermal growth factor receptor 2 (HER2)-positive breast cancer can be treated by HER2targeting agents [60]. Some ER $\alpha$-negative breast tumors that are treated with growth factor receptor inhibitors may reexpress $E R \alpha$ and respond to endocrine therapy [61]. Except for $E R \alpha$, various $E R \beta$ isoforms are expressed in breast cancer. Both ER $\beta 1$ and ER $\beta 2 / c x$ repress the transcriptional activity of $E R \alpha[62]$.

In general, $E R \alpha$ and $E R \beta$ differentially contribute to carcinogenesis and tumor progression with ER $\alpha$ as an oncogene and ER $\beta$ as a tumor suppressor. However, some ER $\beta$ isoforms, such as ER $\beta 5$, may act as oncogene [63]. Studies on the distribution of estrogen receptor (ER) subtypes in ovarian tumors demonstrated that $40-60 \%$ of ovarian cancers express ER $\alpha$, especially in serous tumors and in metastasis [64, 65]. However, less than $20 \%$ of patients (ranging from 7 to $18 \%$ ) respond clinically to anti-estrogen treatment [66]. ER $\beta$ expression, however, is significantly higher in normal ovary tissues compared with ovarian carcinoma [67]. Advanced colon cancer is associated with a loss of ER $\beta$, the predominant ER in colon tissue [11]. ER $\beta$ specific agonists have anti-cancer effects on colon cancer [12]. In addition, estrogen increases the risk of endometrial carcinoma [64]. It appears that ER $\alpha$ is more frequently expressed in lower grade of endometrial carcinoma [68]. ER $\alpha$ expression in endometrial carcinoma is inversely associated with lymph node metastasis [69].

Previous study demonstrated that both ER $\alpha$ and ER $\beta$ were overexpressed in a proportion of hepatitis $C$ virus (HCV)-related hepatocellular carcinoma (HCC) [70]. However, another study shows that the expression of ER $\alpha$ and ER $\beta$ were lower in HCC tissues than in normal liver tissues [71]. The expression of ER $\alpha$ was lower in HCC with portal vein tumor thrombus (PVTT) than those without PVTT, suggesting that ER $\alpha$-positive HCC is less aggressive [72]. In addition, a specific isoform of $\mathrm{ER} \alpha, \mathrm{ER} \alpha-36$, is overexpressed in HCC [73]. Estrogen stimulates HCC cells growth through ER $\alpha-36$ [74]. Therefore, variance in ER $\alpha$ subtypes and isoforms may dictate the response of $\mathrm{HCC}$ to estrogen.

\section{Alternative splicing of ER}

Alternatively spliced ER $\alpha$ mRNA has been detected in both normal and cancerous tissues [71, 75]. Variances in ER $\alpha$ transcripts may lead to loss of ligand-dependent transactivation activity, gain of ligand-independent transactivation activity, and differential response to tamoxifen [76]. The most characterized isoform of ER $\alpha$ is a $66-\mathrm{kDa}$ protein encoded by a 6.6-kb mRNA with eight exons [76].
There are six human ER $\alpha$ mRNA isoforms that encode the same $66-\mathrm{kDa}$ protein but differ in their $5^{\prime}$ untranslated region. Moreover, other variant isoforms of ER $\alpha$ mRNA that encode different proteins from the $66-\mathrm{kDa}$ protein can occur in the presence or absence of wildtype ER $\alpha$ transcript (Fig. 1a). The variance in ER $\alpha$ mRNA may be attributed to frame-shift mutations or alternative splicing [77]. A genomic rearrangement in which ER $\alpha$ exons 6 and 7, which encode part of the ligand-binding domain of $E R \alpha$, are duplicated in an in-frame fashion results in an ER $\alpha$ mRNA that can be translated into a $80 \mathrm{kDa} E R \alpha$ [78]. In addition, a 46-kDa amino-terminal truncated form of ER $\alpha, E R \alpha-46$, has been identified in endothelial cells and breast cancer cells [75]. ER $\alpha-46$ is encoded by an ER $\alpha$ transcript that lacks the first exon of the ER $\alpha$ gene [79]. The high monility group A protein 1a (HMGA1a) induces alternative slicing of ER $\alpha$ thereby increasing ER $\alpha-46$ expresison and reducing tamoxifen sensitivity in breast cancer cells [80]. Mechanistically, HMGA1 traps U1 snRNP at the $5^{\prime}$ splice site of exon 1 in $E R \alpha$ gene thereby inducing alternative splicing [81]. Moreover, some normal or cancer tissues may express the ER $\alpha$ variant that is lack of exon 7 [82]. While the splicing factor HTRA2- $\beta 1$ is responsible for ER $\alpha$ exon 7 inclusion, heterogeneous nuclear ribonucleoprotein (hnRNP) G induces exon 7 skipping and then promotes the generation of the exon 7-skipping isoform of ER $\alpha$ [83]. In addition, a $36-\mathrm{kDa}$ spliced variant of $\mathrm{ER} \alpha, \mathrm{ER} \alpha-$ 36 , has been cloned. ER $\alpha-36$ is defective of exons 1,7 and 8 , which encode transcriptional activation domains AF1 and AF2 [73]. Both ER $\alpha-46$ and ER $\alpha-36$ are located in the plasma membrane, cytosol, and nucleus. ER $\alpha-46$ and $\mathrm{ER} \alpha-36$ can mediate, at least in part, the membrane-initiated estrogen-dependent activation of mitogenic signaling pathways [27]. ER $\alpha$-36 also negatively regulates the transactivation activity of ER $\alpha-66$ and ER $\beta$ [84]. Finally, overexpression of the nuclear protein E3-3 (NPE3-3) promotes the generation of another alternatively spliced variant of $E R \alpha, E R \alpha V$, which contains only exons $1,2,7$ and 8, and encodes a 37-kDa ER $\alpha$ [85]. Notably, NPE3-3 interacts with multiple splicing factors, including serine/ arginine-rich protein (SRp)-30c, SRp40, and splicing factor SC-35 [85].

Variant isoforms of ER $\beta$ have also been identified in both normal and cancerous tissues (Fig. 1b). Alternative splicing of exon 8 in the ER $\beta$ gene results in five ER $\beta$ isoforms (ER $\beta 1, E R \beta 2, E R \beta 3$, ER $\beta 4$ and ER $\beta 5$ ) [86]. The originally cloned ER $\beta$ transcript is termed as ER $\beta 1$, which is the only isoform that is fully functional. The levels of $E R \beta 1$ are low in many tissues, while ER $\beta 2$ (also known as $E R(\beta c x)$ is expressed in many tissues and aggressive cancer [87-91]. ER $\beta 4$ and ER $\beta 5$, however, are predominantly expressed in the testis and placenta, respectively 
a

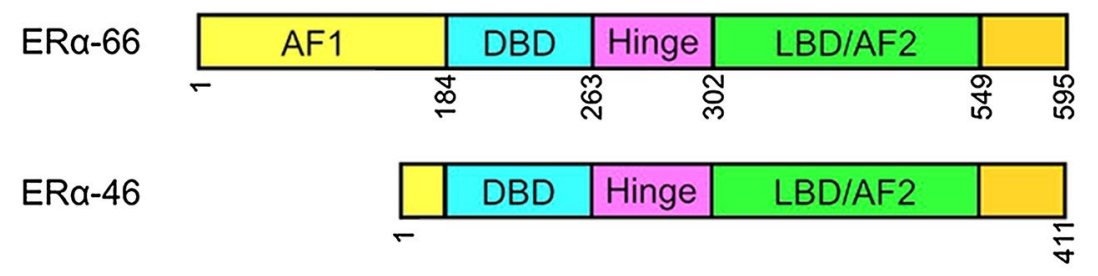

ER $\alpha-36$

b

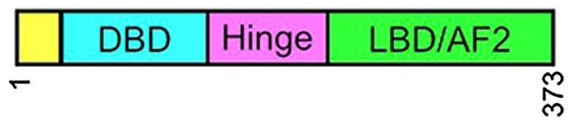

Molecular

weight

$66 \mathrm{kDa}$

(aa)

$46 \mathrm{kDa}$

(aa)

$36 \mathrm{kDa}$

(aa)

\section{)}

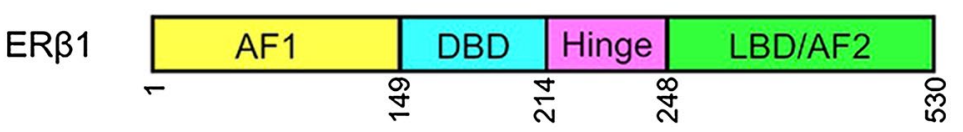

ํㅠ (aa)
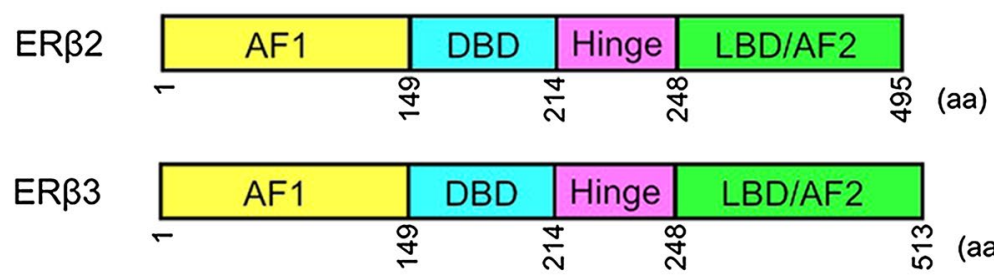

$\frac{m}{i n}$ (aa)

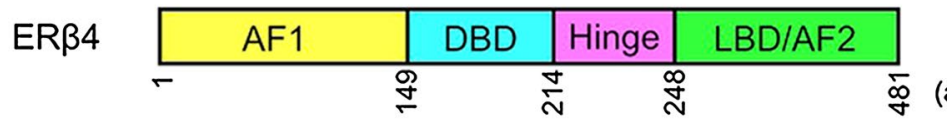

(aa)

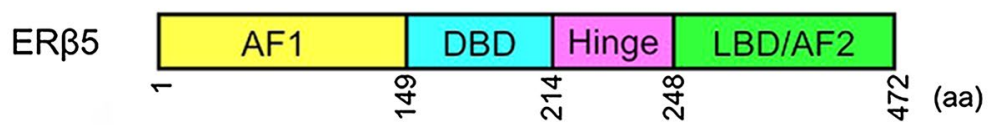

$59 \mathrm{kDa}$

$53 \mathrm{kDa}$

$56 \mathrm{kDa}$

$53 \mathrm{kDa}$

$52 \mathrm{kDa}$

Fig. 1 The major ERa and ER $\beta$ isoforms. a There are three major isoforms of ERa, including ERa-66, ERa-46 and ERa36. ERa-36 differs with ERa-46 in the C-termini. $\mathbf{b} E R \beta$ has five major isoforms, namely ERß1, ERR2, ERß3, ERß4 and ERß5. AF1 activation function 1, AF2 activation function 2, DBD DNA-binding domain, LBD ligand-binding domain

[90]. Both ER $\beta 4$ and ER $\beta 5$ bind to promoter sequences of DNA but do not bind estrogen. ER $\beta 2$, ER $\beta 4$ and ER $\beta 5$ can heterodimerize with $\mathrm{ER} \alpha$ and negatively regulate its transactivation activity [91]. ER $\beta 1$ overexpression is associated with better survival in women with breast cancer [92, 93]. Cytoplasmic expression of ER $\beta 2$ is associated with poor overall survival in patients with breast cancer and serous ovarian carcinoma $[94,95]$. While ER $\beta 1$ has tumor suppressive effects on glioblastoma, ER $\beta 5$ exhibits oncogenic effects on this type of cancer [62]. Moreover, ER $\beta 5$ is associated with poor outcome in HER2-positive and triple-negative breast cancer patients [96]. Taken together, it appears that the ER $\beta$ isoforms have different roles in tumorigenesis. Identification of the relative levels of ER $\beta$ isoforms may help predict the prognosis in cancer patients. The mechanisms underlying the alternative splicing of ER $\beta$ remains largely unknown. The
RNA-binding protein Nova1 can bind to the consensus sequences in the ER $\beta$ pre-mRNA transcript and then promote exon exclusion of the ER $\beta 2$-specific nucleotide sequence, which in turn abolishs ER $\beta 2$ mRNA expression but increases ER $\beta 1$ mRNA expression [97].

\section{Transcriptional regulation of ER expression Transcription factors that regulate ER expression}

The human ER $\alpha$ gene spans approximately $300 \mathrm{~kb}$ of chromosome 6 , including the $140 \mathrm{~kb}$ containing the eight protein-coding exons. Since 1988, intensive efforts have been taken to identify human ER $\alpha$ promoters. The regulation of ER $\alpha$ transcription is controlled by multiple promoters. So far, at least nine promoters have been discovered upstream of the translation start site of human $E R \alpha$. A unified nomenclature for human ER $\alpha$ promoters was suggested by Gannon et al. [98]. The promoters of 
$E R \alpha$ contain multiple transcription factors-binding sites. The availability of these transcription factors may dictate the tissue-specific or context-dependent expression of ER $\alpha$ (Fig. 2a).

Previous studies demonstrated that estrogen receptor promoter B associated factor 1 (ERBF-1) is critical for the transcription activity of a distal promoter (promoter B) in ER $\alpha$-positive breast cancer cells [99]. ERBF-1 is exclusively expressed in cells expressing ER $\alpha$ mRNA transcribed from promoter B and plays an important role in the expression of the ER $\alpha$ gene in breast cancer [100]. In addition, the transcription factor AP2 interacts with cis-regulatory elements via formation of dimers to regulate target gene expression. $\mathrm{ER} \alpha$ expression is associated with AP2 activity in human breast and endometrial cancer [101]. The AP2 family proteins are recognized as key regulators in the development and progression of breast and endometrial cancer [102]. Both AP2 $\alpha$ and AP2 $\gamma$ can trans-activate the human ER $\alpha$ promoter [100]. AP2 $\gamma$ recognizes a region in $E R \alpha$ promoter containing the sequence CCCTGCGGGG thereby inducing changes in the chromatin structure of ER $\alpha$ promoter and stimulating ER $\alpha$ transcription $[103,104]$.

The Forkhead box protein FOXO3a, which can be inactivated by Akt, is a positive regulator of ER $\alpha$ gene transcription [105]. However, FOXO3a interacts with ER $\alpha$ and ER $\beta$ proteins and inhibits ligand-dependent ER signaling and tumorigenesis [106]. FOXM1, another forkhead transcription factor, also regulates ER $\alpha$ transcription. FOXM1 activates the transcriptional activity of human ER $\alpha$ promoter primarily through two closely located forkhead response elements located at the proximal region of the ER promoter [107]. Reciprocally, FOXM1 protein and mRNA expression is regulated by estrogen, tamoxifen and fulvestrant in breast carcinoma. Depletion of ER $\alpha$ in MCF-7 cells down-regulates FOXM1 expression [108]. Moreover, FOXM1 and ER $\alpha$ can simultaneously bind to the same genomic sites and stimulate ER $\alpha$ transcriptional activity [109]. These finding suggest that ER $\alpha$ and FOXM1 may be two key components within a positive cross-regulatory loop.

The GATA proteins are a family of zinc finger DNA binding proteins that recognize the consensus motif $\mathrm{T} / \mathrm{A}$ GATA A/G [110]. GATA-3 is highly expressed in T lymphoid cells and is a master regulator of immune cell function [111]. In the mammary gland, GATA-3 is expressed only by the epithelium and its expression increases during early pregnancy [111]. GATA-3 is an essential regulator of mammary gland morphogenesis and luminal cell differentiation [112]. The expression of GATA-3 is tightly correlated with ER $\alpha$ in human breast carcinoma [113]. GATA-3 binds to two cis-regulatory elements located

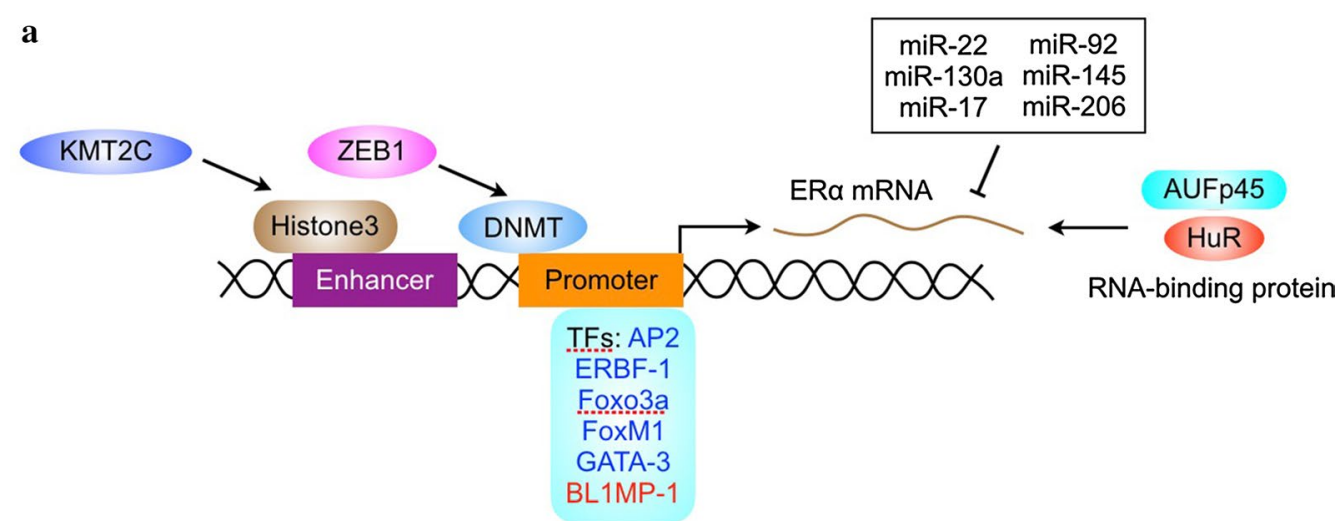

b

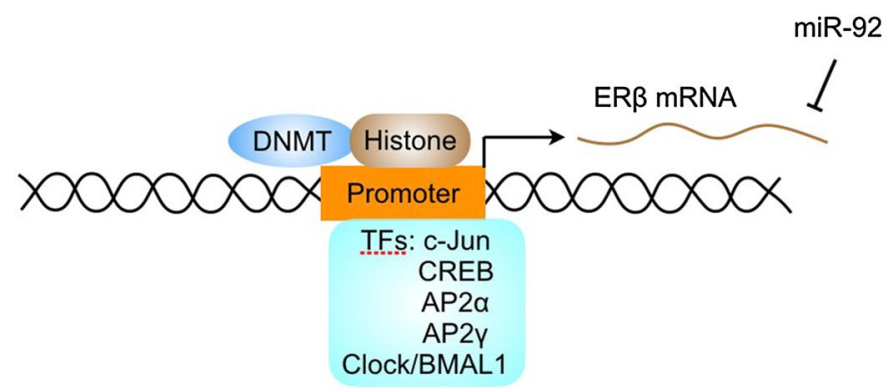

Fig. 2 Mechanisms for regulating ERa and ERß expression. The expression of ERa (a) and ER $\beta$ (b) is regulated by transcription factors (TFs), DNA methylation, histone modification, RNA-binding proteins and miRNA 
within the $E R \alpha$ gene and stimulates ER $\alpha$ transcription [114].

While there are many transcription factors that positivily regulate $\mathrm{ER} \alpha$ expression, little is known about the negative regulators of ER $\alpha$ transcription. The zinc finger repressor B-lymphocyte-induced maturation protein (BLIMP1) is able to bind to ER $\alpha$ promoter and inhibit ER transcription [115]. In addition, the transcription factor $\mathrm{NF}-k \mathrm{~B}$ can indirectly repress $\mathrm{ER} \alpha$ transcription through inducing the expression of BLIMP1 and the Enhancer of Zeste Homolog2 (EZH2), which negatively regulates ER $\alpha$ transcription by inducing the di- and tri-methylation of histone 3 residue $27[20,115]$. However, NF- $k B$ enhances the recruitment of ER $\alpha$ to target DNA and increases the transcriptional activity of ER $\alpha$ [116]. Thus, the levels of ER $\alpha$ may be not always proportional to its activity.

There are several transcription factors that regulate ER $\beta$ transcription (Fig. 2b). The transcription factors $c$-jun and CREB can bind to ER $\beta$ promoter and promote ER $\beta$ transcription [117]. In addition, AP2 $\alpha$ and AP2 $\gamma$, two transcription factors that regulate ER $\alpha$ transcription, bind to $E R \beta$ promoter and stimulate ER $\beta$ transcription [118]. An evolutionally conserved E-box motif (CAC GTG) has been identified in the ER $\beta$ promoter. Transcription factors containing the basic-helix-loop-helix (bHLH) protein structural motif typically bind to E-boxes or related variant sequences and enhance transcription of the downstream gene [119]. CLOCK and BMAL1 are members of the bHLH-PAS family of transcription factors that bind to E-box motifs and induce the transcription of target genes [120]. Both CLOCK and BMAL1 are positive set of components in an envolutionarily conserved feedback loop that controls the oscillation of circadian clock [120]. CLOCK-BMAL1 induces ER $\beta$ transcription via the E-box motif, whereas it does not regulate ER $\beta$ mRNA levels [121].

\section{Epigenetic regulation of ER expression ER promoter methylation}

Gene expression may be silenced by methylation of a cytosine- and guanine-rich area, termed CpG island, in the promoter of the gene [122]. Methylation of CpG islands has been shown to inhibit transcription by preventing the binding of transcription factors to the promoter or by stabilizing structural changes in chromatin that prevent transcription [123]. The absence of ER $\alpha$ gene expression in ER $\alpha$-negative breast cancer cells is associated with abnormal methylation in the CpG islands of multipe promoters of the ER $\alpha$ gene [124, 125]. Mechanistically, methylation of ER $\alpha$ promotet may prevent the recruitment of transcription factor such as AP2. In addition, ZEB1 can induce ER $\alpha$ promoter methylation, downregulate ER $\alpha$ expression and promote anti-estrogen resistance in breast cancer [126]. Treatment of ER $\alpha$ negative human breast cancer cells with demethylating agents can induce partial demethylation of the ER $\alpha$ CpG islands and reactivate ER $\alpha$ gene expression [127]. Inhibition of DNMT1 by antisense oligonucleotides also caused $\mathrm{ER} \alpha$ gene re-expression and the restoration of estrogen responsiveness in ER $\alpha$ negative breast cancer cells [128]. Demethylation of promoter $C$ region in the ER $\alpha$ gene is in part responsible for the enhanced expression of ER $\alpha$ gene in long-term estrogen deprived MCF7 cells [129].

The expression of ER $\beta$ is also regulated by promoter methylation. Two promoters, promoter $0 \mathrm{~K}$ and $0 \mathrm{~N}$, control the transcription of ER- $\beta$ [130]. The lack of ER $\beta 1$, $E R \beta 2$ and ER $\beta 4$ transcription in some breast, ovarian and prostate cancer tissues and cell lines may be attributed to methylation of $\mathrm{CpG}$ sites in the promoter $\mathrm{ON}$ [131]. In contrast, the $0 \mathrm{~K}$ promoter is demethylated in malignant breast and ovarian cancer cells, as well as in normal breast and ovarian epithelial cells $[132,133]$. Hence, ER $\beta$ promoter $0 \mathrm{~N}$ methylation may be a target for manipulating $\mathrm{ER} \beta$ expression.

\section{Histone modification and ER transcription}

Gene transcription is also regulated by chromatin remodeling. The so-called histone code is important for dynamic regulation of chromatin assembly and gene transcription [122]. Chromatin structure is modulated by histone phosphorylation, acetylation, and methylation. Histone acetyltransferases (HAT) transfer an acetyl moiety to lysine residue on histones, leading to neutralization of the positive charge, reduced affinity of histone for DNA, and the transformation of a tight-coiled inactive chromatin structure into a loose, transcriptionally active one [134]. Histone acetylation also plays a role in ER expression. Treatment of ER $\alpha$ negative breast cancer cells with histone deacetylase (HDAC) inhibitors can restore ER $\alpha$ transcription [135]. Moreover, combination of DNA demethylating agents and HDAC inhibitors can induce $E R \alpha$ expression to more extent than treatment of ER $\alpha$ negative breast cancer cells with these agents alone [136]. Moreover, ER $\alpha$ expression is regulated by histone methylation in ER $\alpha$ enhancers. The H3K4 methyltransferase KMT2C up-regulates ER $\alpha$ through regulating H3K4me1 and H3K27ac at ER $\alpha$ enhancers [137]. Regulation of both enhancers and promoters may synergistically affect ER $\alpha$ transcription.

\section{Posttranscriptional regulation of ER expression}

Transcription of the ER $\alpha$ gene gives rise to an mRNA that is $4.3 \mathrm{~kb}$ long and contains an extensive $3^{\prime}$ untranslated region (UTR) that is three-fold longer than its open reading frame [76]. The ER $\alpha 3^{\prime}-\mathrm{UTR}$ is known to contain several regulatory elements, including long tracts of 
AU-rich sequence and 13 copies of AUUUA [138]. AUrich elements may direct mRNA destablization through mechanisms involving polyadenylase tail digestion and distributive deadenylation [139, 140]. Similar to AU rich elements in the $3^{\prime}$-UTR of other transcripts, the AU-rich elements in the $3^{\prime}$-UTR of ER $\alpha$ mRNA play critical roles in ER $\alpha$ mRNA destablization [137]. AUFp45 binds ER $\alpha$ mRNA and increase its stability by protecting it from RNAases [141]. In addition, the RNA-binding protein HuR plays a critical role in stablizing ER $\alpha$ mRNA [142]. It remains to know if there are other RNA-binding proteins that regulate the stability of ER $\alpha$ mRNA.

MicroRNAs (miRNAs) are small non-coding RNA that regulates gene expression at posttranscripton or translational level [143]. Both ER $\alpha$ and ER $\beta$ expression are regulated by miRNAs [144]. The expression of miRNA206 is increased in ER $\alpha$-negative tumors and it directly targets ER $\alpha$ by base pairing to the $3^{\prime}$-untranslated region of the ER $\alpha$ mRNA $[145,146]$. miR-22, miR-130a, miR17/92, miR-145 and miR-206 also directly target ER $\alpha$ mRNA and inhibits its expression [147, 148]. In addition, miR-27a indirectly regulates ER $\alpha$ expression by targeting ZBTB10, a repressor of specificity protein that regulates ER $\alpha$ expression [149]. Interestingly, some of the ER $\alpha$-targeting miRNAs are also regulated by ER $\alpha$. For example, ER $\alpha$ agonists downregulate miR-22, miR206, miR-221, and miR-222 expression [150]. Moreover, miR-92 inhibits ER $\beta 1$ expression by direct targeting the $3^{\prime}$-untranslated region of the ER $\beta$ mRNA [151]. Certainly, there will be more ER $\beta$-targeting miRNAs that may be uncovered in future studies. Furthermore, both $E R \alpha$ and $E R \beta$ regulate the expression of multiple miRNAs [152-156]. Because one miRNA is able to regulate many genes, ER $\alpha$ and ER $\beta$ may link multiple miRNAs to regulate the expression of a large pool of genes.

\section{Concluding remarks}

In light of the critical roles of estrogen receptors signaling in diverse cellular processes and development, it is reasonable that the expression of ER and the activity of ER must be tightly regulated. Deregulation of ER is involved in tumorigenesis in multiple organ sites, including breast, ovary, endometrium and colon. ER expression can be regulated at multiple levels. Dynamic expression of ER is also a feature of human breast cancer. Even in ER-positive breast tumors, the expression of ER is not always permanent. Progression from an ER-positive phenotype to an ER-negative phenotype typically involves the constitutive activation of growth-promoting signals, thereby leading to a loss of estrogen dependence and resistance to anti-estrogens. This increased activation of growth factor receptors correlates with increased MAPK activity $[156,157]$. Abrogation of MAPK activity can reverse the downregulation of ER $\alpha$ by growth factor signaling and restore its activity [158].

The detection of ER $\alpha$ expression in breast cancer is a routine practice in clinical setting. Given that there are multiple isoforms of ER $\alpha$ with different localization and functions, it may be necessary to discriminate which isoform is expressed in human breast cancer specimens. Moreover, the expression of ER $\beta$ isoforms should be detected. Detection of these isoforms may not only guide endocine therapy and/or other emerging therapeutics for breast cancer [159], but also help better judge the progmosis of cancer patients. Except for the levels of ER, the activity of ER may be more critical for the sensitivity to endocine therapy. The levels of estrogen responsive genes may reflect, at least in part, the activity of ER in human breast cancer. Currently, immunohistochemical analysis of PR positivity in human breast cancer is routine procedure in the clinic. Other estrogen responsive genes may also be detected to strenghten this facet.

Since ER $\alpha$-negative breast tumors are less likely to be responsive to endocrine therapy, restoration of ER $\alpha$ expression could allow endocrine therapy to be effective in a subset of $E R \alpha$-negative breast cancer. After reviewing the mechanisms underlying the regulation of ER expression, it is obvious that ER expression can be restored by multiple agents, including signal transduction inhibitors, monoclonal antibodies, DNA-demethylating agents or HDAC inhibitors. In addition, inhibition of Src can enhance ER $\alpha$ expression and anti-estrogen response by preventing ER $\alpha$ proteolysis [160]. Conversion of ER $\alpha$ negative tumors to ER $\alpha$-positive phenotype may allow an endocrine therapy that would prevent tumor progression. Whether or not these approaches can achieve clinical success remains to be determined.

\footnotetext{
Abbreviations

AP: activating protein; E2: estradiol; ER: estrogen receptor; ERBF-1: estrogen receptor promoter $B$ associated factor 1; ERE: estrogen response element; HDAC: histone deacetylase; IGF1: insulin-like growth factor 1; MAPK: mitogenactivated protein kinase; NF-kB: nuclear factor kappa-light-chain-enhancer of activated B cells; PR: progesterone receptor.
}

\section{Authors' contributions}

$\mathrm{HH}$ and $\mathrm{YJ}$ conceived the review and wrote the manuscript. $\mathrm{HZ}$ edited the references. QK prepared the figures. All authors read and approved the final manuscript.

\section{Author details \\ ${ }^{1}$ Laboratory of Stem Cell Biology, West China Hospital, Sichuan University, Chengdu, China. ${ }^{2}$ Laboratory of Oncogene, West China Hospital, Sichuan University, Chengdu, China.}

\section{Acknowledgements}

We would like to thank Qiulin Tang for her assitance in preparing the manuscript.

Competing interests

The authors declare that they have no competing interests. 
Availability of data and materials

Not applicable.

\section{Consent for publication}

Not applicable.

\section{Ethics approval and consent to participate}

Not applicable.

\section{Funding}

Not available.

\section{Publisher's Note}

Springer Nature remains neutral with regard to jurisdictional claims in published maps and institutional affiliations.

Received: 19 July 2018 Accepted: 12 September 2018 Published online: 19 September 2018

\section{References}

1. Hamilton KJ, Hewitt SC, Arao Y, Korach KS. Estrogen hormone biology. Curr Top Dev Biol. 2017;125:109-46.

2. Cui J, Shen Y, Li R. Estrogen synthesis and signaling pathways during aging: from periphery to brain. Trends Mol Med. 2013;19:197-209.

3. Hewitt SC, Korach KS. Estrogen receptors: new directions in the new millennium. Endocr Rev. 2018. https://doi.org/10.1210/er.2018-00087.

4. Chappel SC, Howles C. Reevaluation of the roles of luteinizing hormone and follicle-stimulating hormone in the ovulatory process. Hum Reprod. 1991;6:1206-12.

5. Simpson ER, Davis SR. Minireview: aromatase and the regulation of estrogen biosynthesis - some new perspectives. Endocrinology. 2001;142:4589-94.

6. Folkerd EJ, Dowsett M. Influence of sex hormones on cancer progression. J Clin Oncol. 2010;28:4038-44.

7. Alferez DG, Simões BM, Howell SJ, Clarke RB. The role of steroid hormones in breast and effects on cancer stem cells. Curr Stem Cell Rep. 2018;4:81-94

8. Knutson TP, Truong TH, Ma S, Brady NJ, Sullivan ME, Raj G, et al. Posttranslationally modified progesterone receptors direct ligand-specific expression of breast cancer stem cell-associated gene programs. J Hematol Oncol. 2017;10:89.

9. Sukocheva OA. Estrogen, estrogen receptors, and hepatocellular carcinoma: are we there yet? World J Gastroenterol. 2018;24:1-4.

10. Zheng B, Zhu YJ, Wang HY, Chen L. Gender disparity in hepatocellular carcinoma (HCC): multiple underlying mechanisms. Sci China Life Sci. 2017;60:575-84

11. Stevanato Filho PR, Aguiar Júnior S, Begnami MD, Ferreira FO, Nakagawa WT, Spencer RMSB, et al. Estrogen receptor $\beta$ as a prognostic marker of tumor progression in colorectal cancer with familial adenomatous polyposis and sporadic polyps. Pathol Oncol Res. 2018;24:533-40.

12. Harris HA, Albert LM, Leathurby Y, Malamas MS, Mewshaw RE, Miller CP, et al. Evaluation of an estrogen receptor-beta agonist in animal models of human disease. Endocrinology. 2003;144:4241-9.

13. Wang L, Nanayakkara G, Yang Q, Tan H, Drummer C, Sun Y, et al. A comprehensive data mining study shows that most nuclear receptors act as newly proposed homeostasis-associated molecular pattern receptors. J Hematol Oncol. 2017;10:168.

14. Whitesell L, Santagata S, Mendillo ML, Lin NU, Proia DA, Lindquist S. HSP90 empowers evolution of resistance to hormonal therapy in human breast cancer models. Proc Natl Acad Sci USA. 2014;111:18297-302.

15. Pratt WB, Toft DO. Steroid receptor interactions with heat shock protein and immunophilin chaperones. Endocr Rev. 1997;18:306-60.

16. Welboren WJ, van Driel MA, Janssen-Megens EM, van Heeringen SJ, Sweep FC, Span PN, et al. ChIP-seq of ERalpha and RNA polymerase II defines genes differentially responding to ligands. EMBO J. 2009:28:1418-28.
17. Hall JM, Couse JF, Korach KS. The multifaceted mechanisms of estradiol and estrogen receptor signaling. J Biol Chem. 2001;276:36869-72.

18. Fox EM, Davis RJ, Shupnik MA. ERbeta in breast cancer-onlooker, passive player, or active protector? Steroids. 2008;73:1039-51.

19. Duan R, Ginsburg E, Vonderhaar BK. Estrogen stimulates transcription from the human prolactin distal promoter through AP1 and estrogen responsive elements in T47D human breast cancer cells. Mol Cell Endocrinol. 2008;281:9-18.

20. Sas L, Lardon F, Vermeulen PB, Hauspy J, Van Dam P, Pauwels P, et al. The interaction between ER and NFKB in resistance to endocrine therapy. Breast Cancer Res. 2012;14:212.

21. Ikeda K, Horie-Inoue K, Inoue S. Identification of estrogen-responsive genes based on the DNA binding properties of estrogen receptors using high-throughput sequencing technology. Acta Pharmacol Sin. 2015;36:24-31.

22. Wu C, Zhang HF, Gupta N, Alshareef A, Wang Q, Huang YH, et al. A positive feedback loop involving the Wnt/B-catenin/MYC/Sox2 axis defines a highly tumorigenic cell subpopulation in ALK-positive anaplastic large cell lymphoma. J Hematol Oncol. 2016;9:120.

23. Urano T, Saito T, Tsukui T, Fujita M, Hosoi T, Muramatsu M, et al. Efp targets 14-3-3 sigma for proteolysis and promotes breast tumour growth. Nature. 2002:417:871-5.

24. Finlay-Schultz J, Gillen AE, Brechbuhl HM, Ivie JJ, Matthews SB, Jacobsen $B M$, et al. Breast cancer suppression by progesterone receptors is mediated by their modulation of estrogen receptors and RNA polymerase III. Cancer Res. 2017;77:4934-46.

25. Adlanmerini M, Solinhac R, Abot A, Fabre A, Raymond-Letron I, Guihot $A L$, et al. Mutation of the palmitoylation site of estrogen receptor a in vivo reveals tissue-specific roles for membrane versus nuclear actions. Proc Natl Acad Sci USA. 2014;111:E283-90.

26. Sun Q, Liang Y, Zhang T, Wang K, Yang X. ER-a36 mediates estrogenstimulated MAPK/ERK activation and regulates migration, invasion, proliferation in cervical cancer cells. Biochem Biophys Res Commun. 2017:487:625-32

27. Omarjee S, Jacquemetton J, Poulard C, Rochel N, Dejaegere A, Chebaro $\mathrm{Y}$, et al. The molecular mechanisms underlying the ERa-36-mediated signaling in breast cancer. Oncogene. 2017;36:2503-14.

28. Arnal JF, Lenfant F, Metivier R, Flouriot G, Henrion D, Adlanmerini M, et al. Membrane and nuclear estrogen receptor alpha actions: from tissue specificity to medical implications. Physiol Rev. 2017;97:1045-87.

29. Walter P, Green S, Greene G, Krust A, Bornert JM, Jeltsch JM, et al. Cloning of the human estrogen receptor cDNA. Proc Natl Acad Sci USA. 1985;82:7889-93.

30. Kuiper GG, Enmark E, Pelto-Huikko M, Nilsson S, Gustafsson JA. Cloning of a novel receptor expressed in rat prostate and ovary. Proc Natl Acad Sci USA. 1996;93:5925-30.

31. Anderson E, Clarke RB, Howell A. Estrogen responsiveness and control of normal human breast proliferation. J Mammary Gland Biol Neoplasia. 1998:3:23-35.

32. Soderqvist G, Isaksson E, von Schoultz B, Carlstrom K, Tani E, Skoog $\mathrm{L}$. Proliferation of breast epithelial cells in healthy women during the menstrual cycle. Am J Obstet Gynecol. 1997;176:123-8.

33. Mallepell S, Krust A, Chambon P, Brisken C. Paracrine signaling through the epithelial estrogen receptor $a$ is required for proliferation and morphogenesis in the mammary gland. Proc Natl Acad Sci USA. 2006;103:2196-201.

34. Bondesson M, Hao R, Lin CY, Williams C, Gustafsson JÅ. Estrogen receptor signaling during vertebrate development. Biochim Biophys Acta. 2015;1849:142-51.

35. Couse JF, Korach KS. Estrogen receptor null mice: what have we learned and where will they lead us? Endocr Rev. 1999;20:358-417.

36. Hewitt SC, Winuthayanon W, Korach KS. What's new in estrogen receptor action in the female reproductive tract. J Mol Endocrinol. 2016:56:R55-71.

37. Krege JH, Hodgin JB, Couse JF, Enmark E, Warner M, Mahler JF, et al. Generation and reproductive phenotypes of mice lacking estrogen receptor beta. Proc Natl Acad Sci USA. 1998;95:15677-82.

38. Igarashi H, Kouro T, Yokota T, Comp PC, Kincade PW. Age and stage dependency of estrogen receptor expression by lymphocyte precursors. Proc Natl Acad Sci USA. 2001;98:15131-6. 
39. Andersson A, Törnqvist AE, Moverare-Skrtic S, Bernardi Al, Farman $\mathrm{HH}_{\text {, }}$ Chambon $\mathrm{P}$, et al. Roles of activating functions 1 and 2 of estrogen receptor a in lymphopoiesis. J Endocrinol. 2018;236:99-109.

40. Seto K, Hoang M, Santos T, Bandyopadhyay M, Kindy MS, Dasgupta S. Non-genomic oestrogen receptor signal in B lymphocytes: an approach towards therapeutic interventions for infection, autoimmunity and cancer. Int J Biochem Cell Biol. 2016;76:115-8.

41. Hedges VL, Chen G, Yu L, Krentzel AA, Starrett JR, Zhu JN, et al. Local estrogen synthesis regulates parallel fiber-purkinje cell neurotransmission within the cerebellar cortex. Endocrinology. 2018;159:1328-38.

42. XuY, López M. Central regulation of energy metabolism by estrogens. Mol Metab. 2018. https://doi.org/10.1016/j.molmet.2018.05.012.

43. Ikeda Y, Nagai A. Differential expression of the estrogen receptors alpha and beta during postnatal development of the rat cerebellum. Brain Res. 2006;1083:39-49.

44. Laflamme N, Nappi RE, Drolet G, Labrie C, Rivest S. Expression and neuropeptidergic characterization of estrogen receptors (ERalpha and ERbeta) throughout the rat brain: anatomical evidence of distinct roles of each subtype. J Neurobiol. 1998;36:357-78.

45. Hadjimarkou MM, Vasudevan N. GPER1/GPR30 in the brain: crosstalk with classical estrogen receptors and implications for behavior. J Steroid Biochem Mol Biol. 2018;176:57-64.

46. Morselli E, Santos RS, Gao S, Ávalos Y, Criollo A, Palmer BF, et al. Impact of estrogens and estrogen receptor-a in brain lipid metabolism. Am J Physiol Endocrinol Metab. 2018;315:E7-14.

47. Dubal DB, Zhu H, Yu J, Rau SW, Shughrue PJ, Merchenthaler I, et al. Estrogen receptor alpha, not beta, is a critical link in estradiol-mediated protection against brain injury. Proc Natl Acad Sci USA. 2001;98:1952-7.

48. Rooney AM, van der Meulen MCH. Mouse models to evaluate the role of estrogen receptor a in skeletal maintenance and adaptation. Ann N Y Acad Sci. 2017;1410:85-92.

49. Zhu L, Shi J, Luu TN, Neuman JC, Trefts E, Yu S, et al. Hepatocyte estrogen receptor alpha mediates estrogen action to promote reverse cholesterol transport during Western-type diet feeding. Mol Metab. 2018:8:106-16.

50. Nilsson S, Koehler KF, Gustafsson JÅ. Development of subtypeselective oestrogen receptor-based therapeutics. Nat Rev Drug Discov. 2011;10:778-92

51. Johnson KE, Forward JA, Tippy MD, Ceglowski JR, El-Husayni S, Kulenthirarajan $\mathrm{R}$, et al. Tamoxifen directly inhibits platelet angiogenic potential and platelet-mediated metastasis. Arterioscler Thromb Vasc Biol. 2017;37:664-74

52. Repsold L, Pretorius E, Joubert AM. Ex vivo apoptotic and autophagic influence of an estradiol analogue on platelets. Exp Hematol Oncol. 2016:5:18.

53. Allred DC, Brown P, Medina D. The origins of estrogen receptor alphapositive and estrogen receptor alpha-negative human breast cancer. Breast Cancer Res. 2004;6:240-5.

54. Bertucci F, Finetti P, Cervera N, Charafe-Jauffret E, Buttarelli M, Jacquemier J, et al. How different are luminal A and basal breast cancers? Int J Cancer. 2009;124:1338-48.

55. Brufsky AM, Dickler MN. Estrogen receptor-positive breast cancer: exploiting signaling pathways Implicated in endocrine resistance. Oncologist. 2018;23:528-39.

56. Xu H, Yu S, Liu Q, Yuan X, Mani S, Pestell RG, Wu K. Recent advances of highly selective CDK4/6 inhibitors in breast cancer. J Hematol Oncol. 2017;10:97.

57. Louie MC, Sevigny MB. Steroid hormone receptors as prognostic markers in breast cancer. Am J Cancer Res. 2017;7:1617-36.

58. Dunnwald LK, Rossing MA, Li Cl. Hormone receptor status, tumor characteristics, and prognosis: a prospective cohort of breast cancer patients. Breast Cancer Res. 2007:9:R6.

59. Johnston SR, Saccani-Jotti G, Smith IE, Salter J, Newby J, Coppen M, et al. Changes in estrogen receptor, progesterone receptor, and pS2 expression in tamoxifen-resistant human breast cancer. Cancer Res. 1995;55:3331-8

60. Yu S, Liu Q, Han X, Qin S, Zhao W, Li A, Wu K. Development and clinical application of anti-HER2 monoclonal and bispecific antibodies for cancer treatment. Exp Hematol Oncol. 2017;6:31.

61. Munzone E, Curigliano G, Rocca A, Bonizzi G, Renne G, Goldhirsch $A$, et al. Reverting estrogen-receptor-negative phenotype in
HER-2-overexpressing advanced breast cancer patients exposed to trastuzumab plus chemotherapy. Breast Cancer Res. 2006;8:R4.

62. Liu J, Sareddy GR, Zhou M, Viswanadhapalli S, Li X, Lai Z, et al. Differential effects of estrogen receptor $\beta$ isoforms on glioblastoma progression. Cancer Res. 2018;78:3176-89.

63. Peng B, Lu B, Leygue E, Murphy LC. Putative functional characteristics of human estrogen receptor-beta isoforms. J Mol Endocrinol. 2003;30:13-29.

64. Chuffa LG, Lupi-Júnior LA, Costa AB, Amorim JP, Seiva FR. The role of sex hormones and steroid receptors on female reproductive cancers. Steroids. 2017;118:93-108.

65. Mungenast F, Thalhammer T. Estrogen biosynthesis and action in ovarian cancer. Front Endocrinol (Lausanne). 2014;5:192.

66. Hatch KD, Beecham JB, Blessing JA, Creasman WT. Responsiveness of patients with advanced ovarian carcinoma to tamoxifen. A gynecologic oncology group study of second-line therapy in 105 patients. Cancer. 1991;68:269-71.

67. Chan KK, Wei N, Liu SS, Xiao-Yun L, Cheung AN, Ngan HY. Estrogen receptor subtypes in ovarian cancer: a clinical correlation. Obstet Gynecol. 2008;111:144-51.

68. Budwit-Novotny DA, McCarty KS, Cox EB, Soper JT, Mutch DG, Creasman WT, et al. Immunohistochemical analyses of estrogen receptor in endometrial adenocarcinoma using a monoclonal antibody. Cancer Res. 1986;46:5419-25.

69. Backes FJ, Walker CJ, Goodfellow PJ, Hade EM, Agarwal G, Mutch D, et al. Estrogen receptor-alpha as a predictive biomarker in endometrioid endometrial cancer. Gynecol Oncol. 2016;141:312-7.

70. Iyer JK, Kalra M, Kaul A, Payton ME, Kaul R. Estrogen receptor expression in chronic hepatitis $C$ and hepatocellular carcinoma pathogenesis. World J Gastroenterol. 2017;23:6802-16.

71. Zhang J, Ren J, Wei J, Chong CC, Yang D, He Y, et al. Alternative splicing of estrogen receptor alpha in hepatocellular carcinoma. BMC Cancer. 2016;16:926.

72. Sheng ML, Xu GL, Zhang CH, Jia WD, Ren WH, Liu WB, et al. Aberrant estrogen receptor alpha expression correlates with hepatocellular carcinoma metastasis and its mechanisms. Hepatogastroenterology. 2014;61:146-50.

73. You H, Meng K, Wang ZY. The ER-a36/EGFR signaling loop promotes growth of hepatocellular carcinoma cells. Steroids. 2018;134:78-87.

74. Chantalat E, Boudou F, Laurell H, Palierne G, Houtman R, Melchers D, et al. The AF-1-deficient estrogen receptor ERa46 isoform is frequently expressed in human breast tumors. Breast Cancer Res. 2016;18:123.

75. Hattori Y, Ishii H, Morita A, Sakuma Y, Ozawa H. Characterization of the fundamental properties of the $\mathrm{N}$-terminal truncation ( $\triangle$ exon 1 ) variant of estrogen receptor a in the rat. Gene. 2015;571:117-25.

76. Green S, Walter P, Kumar V, Krust A, Bornert JM, Argos P, et al. Human oestrogen receptor CDNA: sequence, expression and homology to v-erb-A. Nature. 1986;320:134-9.

77. Pfeffer U, Fecarotta E, Arena G, Forlani A, Vidali G. Alternative splicing of the estrogen receptor primary transcript normally occurs in estrogen receptor positive tissues and cell lines. J Steroid Biochem Mol Biol. 1996;56:99-105.

78. Pink JJ, Wu SQ, Wolf DM, Bilimoria MM, Jordan VC. A novel $80 \mathrm{kDa}$ human estrogen receptor containing a duplication of exons 6 and 7 . Nucleic Acids Res. 1996;24:962-9.

79. Flouriot G, Brand H, Denger S, Metivier R, Kos M, Reid G, et al. Identification of a new isoform of the human estrogen receptor-alpha (hERalpha) that is encoded by distinct transcripts and that is able to repress hER-alpha activation function 1. EMBO J. 2000;19:4688-700.

80. Ohe K, Miyajima S, Abe I, Tanaka T, Hamaguchi Y, Harada Y, et al. HMGA1a induces alternative splicing of estrogen receptor alpha in MCF-7 human breast cancer cells. J Steroid Biochem Mol Biol. 2018. https://doi.org/10.1016/j.jsbmb.2018.04.007.

81. Suzuki A, Okuda K, Yano M, Oda R, Sakane T, Kawano O, et al. Exon 7 splicing variant of estrogen receptor $a$ is associated with pathological invasiveness in smoking-independent lung adenocarcinoma. Oncol Lett. 2017;14:891-8.

82. Hirschfeld M, Ouyang YQ, Jaeger M, Erbes T, Orlowska-Volk M, Zur Hausen A, et al. HNRNP G and HTRA2-BETA1 regulate estrogen receptor alpha expression with potential impact on endometrial cancer. BMC Cancer. 2015;15:86. 
83. Wang Z, Zhang X, Shen P, Loggie BW, Chang Y, Deuel TF. A variant of estrogen receptor-alpha, hER-alpha36: transduction of estrogen- and antiestrogen-dependent membrane-initiated mitogenic signaling. Proc Natl Acad Sci USA. 2006;103:9063-8.

84. Ohe K, Miyajima S, Tanaka T, Hamaguchi Y, Harada Y, Horita Y, et al. HMGA1a induces alternative splicing of the estrogen receptor-alpha gene by trapping U1 snRNP to an upstream pseudo-5' splice site. Front Mol Biosci. 2018;5:52.

85. Ohshiro K, Mudvari P, Meng QC, Rayala SK, Sahin AA, Fuqua SA, et al. Identification of a novel estrogen receptor-alpha variant and its upstream splicing regulator. Mol Endocrinol. 2010;24:914-22.

86. Leung YK, Mak P, Hassan S, Ho SM. Estrogen receptor (ER)-beta isoforms: a key to understanding ER-beta signaling. Proc Natl Acad Sci USA. 2006;103:13162-7.

87. Bialesova L, Xu L, Gustafsson JÅ, Haldosen LA, Zhao C, Dahlman-Wright $K$. Estrogen receptor $\beta 2$ induces proliferation and invasiveness of triple negative breast cancer cells: association with regulation of PHD3 and HIF-1a. Oncotarget. 2017;8:76622-33.

88. Dey P, Velazquez-Villegas LA, Faria M, Turner A, Jonsson P, Webb P, et al. Estrogen receptor $\beta 2$ induces hypoxia signature of gene expression by stabilizing HIF-1a in prostate cancer. PLoS ONE. 2015;10:e0128239.

89. Faria M, Karami S, Granados-Principal S, Dey P, Verma A, Choi DS, et al. The ER $\beta 4$ variant induces transformation of the normal breast mammary epithelial cell line MCF-10A; the ER $\beta$ variants ERR2 and ER $\beta 5$ increase aggressiveness of TNBC by regulation of hypoxic signaling. Oncotarget. 2018:9:12201-11.

90. Moore JT, McKee DD, Slentz-Kesler K, Moore LB, Jones SA, Horne EL, et al. Cloning and characterization of human estrogen receptor beta isoforms. Biochem Biophys Res Commun. 1998;247:75-8.

91. Hall JM, McDonnell DP. The estrogen receptor beta-isoform (ERbeta) of the human estrogen receptor modulates ERalpha transcriptional activity and is a key regulator of the cellular response to estrogens and antiestrogens. Endocrinology. 1999;140:5566-78.

92. Reese JM, Suman VJ, Subramaniam M, Wu X, Negron V, Gingery A, et al. ERß1: characterization, prognosis, and evaluation of treatment strategies in ERa-positive and -negative breast cancer. BMC Cancer. 2014;14:749.

93. Wang J, Zhang C, Chen K, Tang H, Tang J, Song C, et al. ERß1 inversely correlates with PTEN/PI3K AKT pathway and predicts a favorable prognosis in triple-negative breast cancer. Breast Cancer Res Treat. 2015;152:255-69.

94. Honma N, Horii R, Iwase T, Saji S, Younes M, Takubo K, et al. Clinical importance of estrogen receptor-beta evaluation in breast cancer patients treated with adjuvant tamoxifen therapy. J Clin Oncol. 2008;26:3727-34

95. Ciucci A, Zannoni GF, Travaglia D, Petrillo M, Scambia G, Gallo D. Prognostic significance of the estrogen receptor beta (ER $\beta$ ) isoforms ERß1, $E R \beta 2$, and ERß5 in advanced serous ovarian cancer. Gynecol Oncol. 2014;132:351-9.

96. Wimberly H, Han G, Pinnaduwage D, Murphy LC, Yang XR, Andrulis IL, et al. ERß splice variant expression in four large cohorts of human breast cancer patient tumors. Breast Cancer Res Treat. 2014;146:657-67.

97. Shults $C L$, Dingwall CB, Kim CK, Pinceti E, Rao YS, PakTR. 17ß-estradiol regulates the RNA-binding protein Nova1, which then regulates thealternative splicing of estrogen receptor $\beta$ in the aging female rat brain. Neurobiol Aging. 2018;61:13-22.

98. Kos M, Reid G, Denger S, Gannon F. Genomic organization of the human ERalpha gene promoter region. Mol Endocrinol. 2001;15:2057-63.

99. Tanimoto K, Eguchi H, Yoshida T, Hajiro-Nakanishi K, Hayashi S. Regulation of estrogen receptor alpha gene mediated by promoter $\mathrm{B}$ responsible for its enhanced expressionin human breast cancer. Nucleic Acids Res. 1999;27:903-9.

100. Yoshida T, Eguchi H, Nakachi K, Tanimoto K, Higashi Y, Suemasu K, et al. Distinct mechanisms of loss of estrogen receptor alpha gene expression in human breast cancer: methylation of the gene and alteration of trans-acting factors. Carcinogenesis. 2000;21:2193-201.

101. Turner BC, Zhang J, Gumbs AA, Maher MG, Kaplan L, Carter D, et al. Expression of AP-2 transcription factors in human breast cancer correlates with the regulation of multiple growth factor signalling pathways. Cancer Res. 1998;58:5466-72.
102. Pellikainen JM, Kosma VM. Activator protein-2 in carcinogenesis with a special reference to breast cancer-a mini review. Int J Cancer. 2007;120:2061-7.

103. MCPherson LA, Weigel RJ. AP2alpha and AP2gamma: a comparison of binding site specificity and trans-activation of the estrogen receptor promoter and single site promoter constructs. Nucleic Acids Res. 1999;27:4040-9.

104. Schuur ER, McPherson LA, Yang GP, Weigel RJ. Genomic structure of the promoters of the human estrogen receptor-alpha gene demonstrate changes in chromatin structure induced by AP2gamma. J Biol Chem. 2001;276:15519-26.

105. Grabinski N, Möllmann K, Milde-Langosch K, Müller V, Schumacher U, Brandt $B$, et al. AKT3 regulates ErbB2, ErbB3 and estrogen receptor a expression and contributes to endocrine therapy resistance of ErbB2(+) breast tumor cells from Balb-neuT mice. Cell Signal. 2014;26:1021-9.

106. Zou Y, Tsai WB, Cheng CJ, Hsu C, Chung YM, Li PC, et al. Forkhead box transcription factor $\mathrm{FOXO}$ a suppresses estrogen-dependent breast cancer cell proliferation and tumorigenesis. Breast Cancer Res. 2008;10:R21.

107. Madureira PA, Varshochi R, Constantinidou D, Francis RE, Coombes RC, Yao KM, et al. The Forkhead box M1 protein regulates the transcription of the estrogen receptor alpha in breast cancer cells. J Biol Chem. 2006;281:25167-76.

108. Millour J, Constantinidou D, Stavropoulou AV, Wilson MS, Myatt SS, Kwok JM, et al. FOXM1 is a transcriptional target of ERalpha and has a critical role in breast cancer endocrine sensitivity and resistance. Oncogene. 2010;29:2983-95.

109. Sanders DA, Ross-Innes CS, Beraldi D, Carroll JS, Balasubramanian S. Genome-wide mapping of FOXM1 binding reveals co-binding with estrogen receptor alpha in breast cancer cells. Genome Biol. 2013;14:R6.

110. Fujiwara T. GATA transcription factors: basic principles and related human disorders. Tohoku J Exp Med. 2017;242:83-91.

111. Ormandy CJ, Naylor M, Harris J, Robertson F, Horseman ND, Lindeman $\mathrm{GJ}$, et al. Investigation of the transcriptional changes underlying functional defects in the mammary glands of prolactin receptor knockout mice. Recent Prog Horm Res. 2003;58:297-323.

112. Asselin-Labat ML, Sutherland KD, Barker H, Thomas R, Shackleton $M$, Forrest NC, et al. Gata-3 is an essential regulator of mammarygland morphogenesis and luminal-cell differentiation. Nat Cell Biol. 2007:9:201-9.

113. Guo Y, Yu P, Liu Z, Maimaiti Y, Chen C, Zhang Y, et al. Prognostic and clinicopathological value of GATA binding protein 3 in breast cancer: a systematic review and meta-analysis. PLoS ONE. 2017;12:e0174843.

114. Eeckhoute J, Keeton EK, Lupien M, Krum SA, Carroll JS, Brown M. Positive cross-regulatory loop ties GATA-3 to estrogen receptor alpha expression in breast cancer. Cancer Res. 2007;67:6477-83.

115. Wang X, Belguise K, O'Neill CF, Sánchez-Morgan N, Romagnoli M, Eddy $S F$, et al. RelB NF-kappaB represses estrogen receptor alpha expression via induction of the zinc finger protein Blimp1. Mol Cell Biol. 2009;29:3832-44.

116. Frasor J, El-Shennawy L, Stender JD, Kastrati I. NFkB affects estrogen receptor expression and activity in breast cancer through multiple mechanisms. Mol Cell Endocrinol. 2015:418:235-9.

117. Zhou Y, Zeng C, Li X, Wu PL, Yin L, Yu XL, et al. IGF-I stimulates ER $\beta$ and aromatase expression via IGF1R/PI3K/AKT-mediated transcriptional activation in endometriosis. J Mol Med. 2016;94:887-97.

118. Zhang $X$, Leung YK, Ho SM. AP-2 regulates the transcription of estrogen receptor (ER)-beta by acting through a methylation hotspot of the $0 \mathrm{~N}$ promoter in prostate cancer cells. Oncogene. 2007;26:7346-54.

119. Kewley RJ, Whitelaw ML, Chapman-Smith A. The mammalian basic helix-loop-helix/PAS family of transcriptional regulators. Int J Biochem Cell Biol. 2004;36:189-204.

120. Hastings MH, Maywood ES, Brancaccio M. Generation of circadian rhythms in the suprachiasmatic nucleus. Nat Rev Neurosci. 2018. https ://doi.org/10.1038/s41583-018-0026-z.

121. Cai W, Rambaud J, Teboul M, Masse I, Benoit G, Gustafsson JA, et al. Expression levels of estrogen receptor beta are modulated by components of the molecular clock. Mol Cell Biol. 2008;28:784-93.

122. Nebbioso A, Tambaro FP, Dell'Aversana C, Altucci L. Cancer epigenetics: moving forward. PLoS Genet. 2018;14:e1007362. 
123. Comb M, Goodman HM. CpG methylation inhibits proenkephalin gene expression and binding of the transcription factor AP-2. Nucleic Acids Res. 1990;18:3975-82.

124. Jiménez-Garduño AM, Mendoza-Rodríguez MG, Urrutia-Cabrera D, Domínguez-Robles MC, Pérez-Yépez EA, Ayala-Sumuano JT, et al. IL-1 $\beta$ induced methylation of the estrogen receptor ERa gene correlates with EMT and chemoresistance in breast cancer cells. Biochem Biophys Res Commun. 2017:490:780-5.

125. Tsuboi K, Nagatomo T, Gohno T, Higuchi T, Sasaki S, Fujiki N, et al. Single $\mathrm{CpG}$ site methylation controls estrogen receptor gene transcription and correlates with hormone therapy resistance. J Steroid Biochem Mol Biol. 2017;171:209-17.

126. Zhang J, Zhou C, Jiang H, Liang L, Shi W, Zhang Q, et al. ZEB1 induces ER-a promoter hypermethylation and confers antiestrogen resistance in breast cancer. Cell Death Dis. 2017;8:e2732.

127. Ferguson AT, Lapidus RG, Baylin SB, Davidson NE. Demethylation of the estrogen receptor gene in estrogen receptor-negative breast cancer cells can reactivate estrogen receptor gene expression. Cancer Res. 1995;55:2279-83.

128. Yan L, Nass SJ, Smith D, Nelson WG, Herman JG, Davidson NE. Specific inhibition of DNMT1 by antisense oligonucleotides induces re-expression of estrogen receptor-alpha (ER) in ER-negative human breast cancer cell lines. Cancer Biol Ther. 2003;2:552-6.

129. Sogon T, Masamura S, Hayashi S, Santen RJ, Nakachi K, Eguchi H. Demethylation of promoter $C$ region of estrogen receptor alpha gene is correlated with its enhanced expression in estrogen-ablation resistant MCF-7 cells. J Steroid Biochem Mol Biol. 2007;105:106-14.

130. Hirata S, Shoda T, Kato J, Hoshi K. The multiple untranslated first exons system of the human estrogen receptor beta (ER beta) gene. J Steroid Biochem Mol Biol. 2001;78:33-40.

131. Božović A, Markićević M, Dimitrijević B, Jovanović Ćupić S, Krajnović M, Lukić $S$, et al. Potential clinical significance of ERß ON promoter methylation in sporadic breast cancer. Med Oncol. 2013;30:642.

132. Suzuki F, Akahira J, Miura I, Suzuki T, Ito K, Hayashi S, et al. Loss of estrogen receptor beta isoform expression and its correlation with aberrant DNA methylation of the 5'-untranslated region in human epithelial ovarian carcinoma. Cancer Sci. 2008;99:2365-72.

133. Zhao C, Lam EW, Sunters A, Enmark E, De Bella MT, Coombes RC, et al. Expression of estrogen receptor beta isoforms in normal breast epithelial cells and breast cancer: regulation by methylation. Oncogene. 2003;22:7600-6.

134. Demetriadou C, Kirmizis A. Histone acetyltransferases in cancer: guardians or hazards? Crit Rev Oncog. 2017;22:195-218.

135. Stark K, Burger A, Wu J, Shelton P, Polin L, Li J. Reactivation of estrogen receptor a by vorinostat sensitizes mesenchymal-like triple-negative breast cancer to aminoflavone, a ligand of the aryl hydrocarbon receptor. PLoS ONE. 2013;8:e74525.

136. Yang $X$, Phillips DL, Ferguson AT, Nelson WG, Herman JG, Davidson NE. Synergistic activation of functional estrogen receptor (ER)-alpha by DNA methyltransferase and histone deacetylase inhibition in human ER-alpha-negative breast cancer cells. Cancer Res. 2001;61:7025-9.

137. Gala K, Li Q, Sinha A, Razavi P, Dorso M, Sanchez-Vega F, et al. KMT2C mediates the estrogen dependence of breast cancer through regulation of ERa enhancer function. Oncogene. 2018. https://doi. org/10.1038/s41388-018-0273-5.

138. Kenealy MR, Flouriot $G$, Sonntag-Buck V, Dandekar T, Brand H, Gannon F. The $3^{\prime}$-untranslated region of the human estrogen receptor alpha gene mediates rapid messenger ribonucleic acid turnover. Endocrinology. 2000;141:2805-13.

139. Chen $C Y, X u N$, Shyu AB. mRNA decay mediated by two distinct AU-rich elements from c-fos and granulocyte-macrophage colony-stimulating factor transcripts: different deadenylation kinetics and uncoupling from translation. Mol Cell Biol. 1995;15:5777-88.

140. Xu N, Chen CY, Shyu AB. Modulation of the fate of cytoplasmic mRNA by AU-rich elements: key sequence features controlling mRNA deadenylation and decay. Mol Cell Biol. 1997;17:4611-21.

141. Ing NH, Massuto DA, Jaeger LA. Estradiol up-regulates AUF1p45 binding to stabilizing regions within the $3^{\prime}$-untranslated region of estrogen receptor alpha mRNA. J Biol Chem. 2008;283:1764-72.
142. Pryzbylkowski P, Obajimi O, Keen JC. Trichostatin A and 5 Aza-2' deoxycytidine decrease estrogen receptor mRNA stability in ER positive MCF7 cells through modulation of HuR. Breast Cancer Res Treat. 2008;111:15-25.

143. Abdi J, Rastgoo N, Li L, Chen W, Chang H. Role of tumor suppressor p53 and micro-RNA interplay in multiple myeloma pathogenesis. J Hematol Oncol. 2017; 10:169.

144. Guttilla IK, Adams BD, White BA. ERa, microRNAs, and the epithelialmesenchymal transition in breast cancer. Trends Endocrinol Metab. 2012;23:73-82.

145. Iorio MV, Ferracin M, Liu CG, Veronese A, Spizzo R, Sabbioni S, et al. MicroRNA gene expression deregulation in human breast cancer. Cancer Res. 2005;65:7065-70.

146. Adams BD, Furneaux H, White BA. The micro-ribonucleic acid (miRNA) miR-206 targets the human estrogen receptor-alpha (ERalpha) and represses ERalpha messenger RNA and protein expression in breast cancer cell lines. Mol Endocrinol. 2007:21:1132-47.

147. Pandey DP, Picard D. miR-22 inhibits estrogen signaling by directly targeting the estrogen receptor alpha mRNA. Mol Cell Biol. 2009;29:3783-90.

148. Castellano L, Giamas G, Jacob J, Coombes RC, Lucchesi W, Thiruchelvam $P$, et al. The estrogen receptor-alpha-induced microRNA signature regulates itself and its transcriptional response. Proc Natl Acad Sci USA. 2009;106:15732-7.

149. Li X, Mertens-Talcott SU, Zhang S, Kim K, Ball J, Safe S. MicroRNA-27a indirectly regulates estrogen receptor alpha expression and hormone responsiveness in MCF-7 breast cancer cells. Endocrinology. 2010:151:2462-73.

150. Di Leva G, Gasparini P, Piovan C, Ngankeu A, Garofalo M, Taccioli C, et al. MicroRNA cluster 221-222 and estrogen receptor alpha interactions in breast cancer. J Natl Cancer Inst. 2010;102:706-21.

151. Al-Nakhle H, Burns PA, Cummings M, Hanby AM, Hughes TA, Satheesha $\mathrm{S}$, et al. Estrogen receptor $\{$ beta\} 1 expression is regulated by miR-92 in breast cancer. Cancer Res. 2010;70:4778-84.

152. Cicatiello L, Mutarelli M, Grober OM, Paris O, Ferraro L, Ravo M, et al. Estrogen receptor alpha controls a gene network in luminal-like breast cancer cells comprising multiple transcription factors and microRNAs. Am J Pathol. 2010;176:2113-30.

153. Zhang W, Wu M, Chong QY, Zhang M, Zhang X, Hu L, et al. Loss of estrogen-regulated MIR135A1 at 3p21.1 promotes tamoxifen resistance in breast cancer. Cancer Res. 2018. https://doi.org/10.1158/0008-5472. CAN-18-0069.

154. Jiang CF, Shi ZM, Li DM, Qian YC, Ren Y, Bai XM, et al. Estrogen-induced miR-196a elevation promotes tumor growth and metastasis via targeting SPRED1 in breast cancer. Mol Cancer. 2018;17:83.

155. Paris O, Ferraro L, Grober OM, Ravo M, De Filippo MR, Giurato G, et al. Direct regulation of microRNA biogenesis and expression by estrogen receptor beta in hormone-responsive breast cancer. Oncogene. 2012;31:4196-206.

156. Gee JM, Robertson JF, Ellis IO, Nicholson RI. Phosphorylation of ERK1/2 mitogen-activated protein kinase is associated with poor response to anti-hormonal therapy and decreased patient survival in clinical breast cancer. Int J Cancer. 2001;95:247-54.

157. Jeng MH, Yue W, Eischeid A, Wang JP, Santen RJ. Role of MAP kinase in the enhanced cell proliferation of long term estrogen deprived human breast cancer cells. Breast Cancer Res Treat. 2000;62:167-75.

158. Oh AS, Lorant LA, Holloway JN, Miller DL, Kern FG, El-Ashry D. Hyperactivation of MAPK induces loss of ERalpha expression in breast cancer cells. Mol Endocrinol. 2001;15:1344-59.

159. Hu X, Huang W, Fan M. Emerging therapies for breast cancer. J Hematol Oncol. 2017:10:98

160. Chu I, Arnaout A, Loiseau S, Sun J, Seth A, McMahon C, et al. SrC promotes estrogen-dependent estrogen receptor alpha proteolysis in human breast cancer. J Clin Invest. 2007;117:2205-15. 